\title{
Re-bundling and the Development of Hollow Clusters in the East German Chemical Industry
}

\author{
Harald Bathelt
}

\begin{abstract}
Version Post-print/accepted manuscript
Citation Bathelt, H. (2009). Re-bundling and the development of hollow clusters (published version) in the East German chemical industry. European Urban and Regional Studies, 16(4), 363-381.

Copyright / License

Publisher's Statement The version of record [Bathelt, H. (2009). Re-bundling and the development of hollow clusters in the East German chemical industry. European Urban and Regional Studies, 16(4), 363-381.] is available online at: http://eur.sagepub.com/content/16/4/363.short [doi: 10.1177/0969776409340193]
\end{abstract}

Always cite the published version, so the author(s) will receive recognition through services that track citation counts, e.g. Scopus. If you need to cite the page number of the TSpace version (original manuscript or accepted manuscript) because you cannot access the published version, then cite the TSpace version in addition to the published version using the permanent URI (handle) found on the record page. 


\section{Re-bundling and the Development of Hollow Clusters in the East German Chemical Industry}

by

Harald Bathelt

University of Toronto, Department of Political Science and Department of Geography, Sidney Smith Hall, 100 St. George Street, Toronto ON M5S 3G3, Canada,

E-mail: harald.bathelt@utoronto.ca,

URL: http://www.harald-bathelt.com

Paper to be submitted to

European Urban and Regional Studies 


\title{
Re-bundling and the Development of Hollow Clusters in the East German Chemical Industry
}

\begin{abstract}
After the reunification, drastic economic restructuring processes occurred in East Germany due to a double transition: the transformation of the political and economic system, and the Fordist crisis associated with ongoing globalisation processes. The challenges and shifts were particularly strong in the chemical industry, which had developed a structure of mass production characterised by an unsustainable exploitation of natural and economic resources. Drawing on a conception that views transformation and restructuring as a process of regional ruptures and re-bundling, rather than one that focuses on the lock-in of old industrialised regions, this paper investigates the extent to which restructuring activities have been able to generate self-sustaining regional economies and networks in the East German chemical industry. The study is based on empirical research conducted in the regions of Leuna, Schkopau and Bitterfeld-Wolfen, which provides evidence that restructuring in the chemical industry did not create fully-fledged clusters with strong interfirm linkages. Although the regional economies of the East German chemical industry were well-linked to West Germany and to international markets through corporate ties, networks for learning and innovation remained weak. The development of these "hollow clusters" was due to the persistence of a small industry basis, the dominance of branch operations with few local ties, and the limited importance of start-up firms. Such conditions, consequently, limit the prospects for growth in the East German chemical industry, suggesting that more diversified regional policies must be developed in the future.
\end{abstract}

Keywords: German reunification, East Germany, chemical industry, regional re-bundling, hollow clusters 


\section{Introduction: East Germany's Bumpy Transition after Reunification}

The German reunification in 1990 placed great challenges on the East German political economy in terms of restructuring to gain economic strength. With reunification, the former planned economy was abandoned and replaced by a market-based economic system. This meant that formal institutions, laws and rules for economic production and interaction, and the financial system and currency were transformed without an extended period of adjustment (e.g. Schüller 1990). Prior economic structures were substituted for those structures that already existed in West Germany at that time, accompanied by drastic changes in the manufacturing sector, which caused widespread dissatisfaction and frustration among the East German workforce (e.g. Thomas 2005; Land 2006). First, existing economic organisations were transformed from large hierarchical state-owned firms (Kombinate) into smaller privately-owned firms. Existing vertically-integrated industrial systems with rigid top-down hierarchies were broken up and systematically disintegrated. New owners, buyers or investors had to be found to take over managerial control of the individual parts of these industrial systems. Second, many of the manufacturing activities were characterized by outdated technologies and low productivity rates and thus had to be modernised to become competitive. Third, the result of these restructuring activities was that the manufacturing sector laid off hundreds of thousands of workers. Within less than a decade, manufacturing employment decreased by $70-90 \%$ and unemployment figures increased drastically to a level of 20-30\% (Land 2006).

Overall, the reunification period left many East Germans sceptical of the strengths of the West German market economy and its formal institutions. This distrust proved to be a barrier to the generation of new industry networks (e.g. Metze and Schroeckh 1998; Thomas 2003). In many ways, such challenges were particularly strong in the East German chemical industry, 
which is the focus of this paper. In the post-World War II period, this industry had developed into a strong economic branch exporting its products to many other Comecon (Council for Mutual Economic Assistance) countries (Bathelt 1995).

Writing almost 20 years after reunification, this paper explores the degree to which restructuring processes and new investments have been successful in establishing sound regional economies with long-term growth potential and in making up for the job losses after reunification. It investigates whether self-sustained industrial configurations, characterised by competitive interfirm networks and innovation potential, have developed in the chemical industry. The paper analyses this by developing a conceptualisation that combines different approaches. In particular, it integrates evolutionary accounts with concepts of re-bundling and "hollow clusters". It is hypothesised that this conceptualisation provides a better understanding of the regional consequences of political transformation and economic restructuring, especially in the context of the East German economy. The study suggests that re-bundling processes in the chemical industry partially failed to create self-sustained regional growth due to the fact that start-up processes were not initiated and that remnants of the former industry structure were not able to stimulate substantial growth. Furthermore, new branch operations in West German and foreign firms have stagnated in recent years. The concept of "hollow clusters" is used to characterise the structure of chemical production that resulted from regional re-bundling processes. At present, the regions investigated in this paper remain characterised by sparse internal input-output linkages, locally embedded ties and knowledge linkages. Such structures have a limited capacity to extend growth impulses without the establishment of strong corporate ties or "global pipelines". This suggests that the regional growth potential of the East German chemical industry may be severely constrained. 
The analysis of the consequences of regional re-bundling in the East German chemical industry is carried out in a qualitative fashion, investigating the economic action and interaction of established and new chemical firms. In particular, transformation processes in three important chemical industry regions concentrated in the Land Sachsen-Anhalt will be explored. As this research aims to provide an overview of the regions and conduct a comparative analysis, it draws on many different types of information sources, including the relevant academic literature, newspaper and other media publications, as well as industry documents, websites and unpublished information material. At the same time, the research is also based on more than 120 interviews conducted with managers, politicians, regional planners and industry observers between 1994 and 2006. East German chemical regions were visited almost every year during this time period, and interviews were conducted with the management of firms or experts from policy organisations. This multiplicity of sources was used to triangulate the information received. As a whole, this study captures the developments and challenges of the restructuring processes in the most important East German chemical regions. ${ }^{1}$ In so doing, it provides important insights into the nature of the restructuring processes that took place after reunification.

The paper is structured as follows: Section 2 presents the conceptual basis of the analysis, which draws upon a network and cluster perspective, and argues that the reunification process was associated with restructuring and re-bundling activities. Section 3 provides a short overview of the growth and transformation of the East German chemical industry before and after World War II. Section 4 investigates the restructuring processes in three East German chemical industry regions in Sachsen-Anhalt: Leuna, Schkopau (including Böhlen), and Bitterfeld-Wolfen. Finally, section 5 draws conclusions regarding the prospects for future growth and competitiveness in these regions. 


\section{Toward a Conceptualisation: Networks, Ruptures and Re-bundling}

One could argue that the state of the manufacturing regions in East Germany at the time of reunification resembled that of the old industrialised regions in West Germany and other capitalist economies. These were traditional, sometimes single-sector manufacturing regions that had lost part of their competitiveness. Related analyses are often based on an evolutionary perspective, which argues that technological development is highly dependent on existing structures and prior technological decisions, rather than on a process driven by optimal decisionmaking. Evolutionary economics posits that techno-economic change defines a development path that follows particular routines and heuristics (Nelson and Winter 1982; Dosi 1988). Accordingly, the direction of technological change is viewed as pre-structured by existing technologies, albeit not in a deterministic way. From this perspective, decisions about technologies made at one point in time initiate processes of selection, mutation, variation, and chance at a later point. Problems can occur in this development if existing configurations cannot be easily reversed, or if they prevent necessary adaptations. David's (1985) and Arthur's (1988) work tells us that such technological lock-in is often related to rigid institutional conditions and externalities. Although lock-in situations can be a source of high economic returns over the long term, they have also been associated with negative connotations, leading, for example, to a "catch 22" situation or to one in which superior technological choices are ruled out (Setterfield 1993; Martin and Sunley 2006).

Negative lock-in situations have also been studied in regional contexts where localised industrial systems have collectively run into problems due to rigid technological and organisational structures. These rigid structures have often developed due to the technological choices of the dominant industry, sometimes reliant on few large firms and their supplier networks. Grabher (1993) has explained this in terms of the power of strong ties between the 
economic and political actors in a region which can block off radically new ideas and alternative developments from outside. Entire regional economies can lose their competitive edge and run into trouble, as in the case of iron and steel production in the German Ruhr (Grabher 1993) or watch-making in the Swiss Jura (Maillat et al. 1995). Grabher (1993) distinguishes three types of lock-in situations that can threaten regional development: (a) cognitive lock-in which occurs if the regional actors collectively focus too strongly on the dominant technological path; (b) functional lock-in, or over-embeddedness (Uzzi 1997), related to the existence of input-output relations that are too close, often involving a small group of dominant actors; and (c) political lock-in due to narrow-sided political programs and overly strong bonds between the dominant economic and political cadres (see, also, Hassink 2005).

Although this literature provides important insights into the design of regional policies, the goal of overcoming lock-in only partially fits the situation of the East German chemical industry after reunification. Even though this industry could be considered a mature industry at that time, due to its outdated technological and organisational structure (Dühr 1998), it will be argued below that the literature on lock-in does not fully apply to the East German case. Certainly, the evolution of the East German chemical industry in the post-World War II period led to multiple lock-in situations. The most dramatic barrier to integrating East Germany into global economic circuits relates to what could be referred to as a "systemic lock-in". ${ }^{2}$ This situation is characterised by a hierarchical state-planned economy that operates under drastically different institutional and organisational conditions from those of a market economy (Schüller 1990; Merkel 1999). By transforming the political and economic system of East Germany, and replacing it with the West German system, the main obstacles to restructuring the manufacturing sector were eliminated. Because the transformation was associated with massive closures of old, uncompetitive manufacturing operations and the dissolution of existing ties between the former 
political and economic elites, many of the potential causes of classical lock-in situations were removed. ${ }^{3}$

A different problem arose, however, as a direct result of this restructuring and became an issue in the reconstruction of the East German economy. More specifically, the East German economy lacked the regional networks that are viewed as essential to economic growth and competitiveness. Especially from to the work of Porter (1990), it has become widely accepted that economic competitiveness is not just a function of a firm's individual capabilities and competencies, but that it is also shaped by the competitive environment and collective networks within which the firm operates. In particular, regional clusters of specialised industries and their support and service infrastructure, which are connected through traded and untraded interdependencies, are viewed as decisive building blocks to support collective competitiveness within a regional economy (Malmberg and Maskell 2002; Bathelt 2005). The success and possible innovative capability of specialised industry clusters is based on their ability to develop a strong (horizontal) set of competing firms and (vertical) producer-user networks. These networks support the dissemination of knowledge, reduction of transaction costs, and enable wider learning processes. Of course, the success of clusters cannot be reduced to producer-user linkages alone. They also depend strongly on the development of the institutional and political framework to support reproduction and innovation, as well as power relations and power structures affecting the possibility to engage others in joint action. This includes wider policy networks related to education and training facilities and municipal, regional and federal economic support policies.

An early analysis of Albach (1993) pointed out that horizontal and vertical producer-user networks were missing after the reunification. The dissolution and restructuring of state-directed, vertically-integrated manufacturing firms led to the establishment of ruptured "truncated 
networks". This proved to be problematic as firms had no experience in finding and dealing with transaction partners in a market environment (Schmidt 1997). The results of various studies regarding regional networks and networking behaviour of East German firms are, however, inconclusive (Brussig 2000). In a large postal survey, Fritsch et al. (1998), for instance, provided evidence that firms in Saxony had higher rates of interfirm cooperation than their counterparts in West Germany. Despite this high incidence of networking, these firms were found to be less innovative than the West German firms. Grabher's (1996) intensive case studies in Brandenburg exemplified that remnants of former production networks were not dense and varied enough to stimulate the creation of new networks. Firms also seemed to be sceptical about the advantages of networks (e.g. Metze and Schroeckh 1998) and were worried about unintended know-how outflows. Despite some variation in the empirical evidence, one of the challenges of establishing self-sustaining growth in East German regions seemed to be the establishment of new economic networks through which learning processes could be channelled and innovation triggered (e.g. Koschatzky and Zenker 1999).

Recent discussions have shown that the success of clusters not only depends on regional transaction networks and input-output linkages alone, but is also substantially shaped by wider knowledge flows that exist within a cluster and with its outside environment. This includes linkages or "pipelines" to markets, technologies and knowledge pools in other regions and nations (Bathelt et al. 2004). The success of these regional industry configurations is dependent on a systematic combination and integration of local cluster-internal and global cross-cluster transaction networks, which transfer growth impulses and new knowledge into the cluster networks (Scott 1998). Systematic external linkages can be crucial in order to gain access to technological breakthroughs and avoid lock-in (Owen-Smith and Powell 2004). In the process of reconstructing the East German chemical industry, access to these global knowledge pipelines 
was seemingly not the most urgent shortcoming, as restructuring was based on the involvement of multinational firms from West Germany and other market economies. These firms brought access to the global technology and market environment and equipped local operations with stateof-the-art technologies. As shown below, this involved heavy subsidies which were jointly supplied by the federal and Länder governments through the "Gemeinschaftsaufgabe zur Verbesserung der regionalen Wirtschaftsstruktur" (joint task for the improvement of regional economies), a nation-wide regional economic support policy which was substantially revised after reunification to accommodate the economic needs of the new Länder (e.g. Klemmer 1995).

The subsequent analysis of this context of economic restructuring will draw upon an evolutionary perspective (e.g. Boschma and Lamboy 1999). Similar to the view of Storper and Walker (1989), it is assumed that geographic industrialisation processes are driven by innovative industries and technologies, which shape the regional development path (Bathelt and Glückler 2003). Instead of over-emphasising continuity in technological development, as is sometimes done in evolutionary accounts, special attention is paid to the effects of political ruptures and economic crises. As suggested by Bathelt and Boggs (2003), these crises can result in discontinuous shifts in regional technological trajectories. This view suggests that regional development is driven by bundles of overlapping technological trajectories, characterised both by the effects of incremental, cumulative learning processes and unexpected discontinuities. Drawing from North American experience, Feldman and Francis (2006) have argued that in periods of crises and discontinuities entrepreneurial potential can be mobilised, resulting in the establishment of new firms which might drive regional development later on. Similarly, the concept of re-bundling used to conceptualise the drastic restructuring processes of the East German chemical industry after reunification views political ruptures and sectoral crises not just as straining regional economies, but also as situations that open up new opportunities for the 
formation of networks (Bathelt and Boggs 2003). Re-bundling draws attention to the wider actor-networks at work in a region and their access to resources. It involves the mobilisation and introduction of new/renewed local assets and liabilities. This concept also shares some parallels with Bourdieu's (1988) understanding of historical sequences of events. Discontinuities disrupt existing transactional networks, while simultaneously releasing resources for alternative uses.

A crisis leads to two kinds of adjustments: (i) geographical shifts, as assets leave the region; and (ii) sectoral/technological shifts, as assets are redeployed to the region's other sectors and technologies. Opportunities for reconstruction are greater, of course, if geographical shifts do not become the dominant strategy of adjustment. Through sectoral/technological shifts, innovations developed in one sector filter into another. This may generate new opportunities for growth if resources can be mobilised for new creative uses and eventually attract new capital from outside. These shifts are investigated below in the case of three core regions of the East German chemical industry.

Regions begin to recover from ruptures when agents re-bundle the capital at hand (i.e. financial, physical, human and social capital) for a new round of accumulation. Sometimes this becomes the basis of a new regional industry core, which may promote a novel development path as new ventures are started. In order to shape a region's development path so that the local effects of a crisis are overcome, a new ensemble of competencies must develop. This must be anchored in the local economy by non-ubiquitous resources found within a specialised social division of labour. This development must be characterised by a certain size, encompass regional networks of learning and knowledge exchange, and a specialised labour market, to have a substantial impact. A region must also develop a wider set of institutions to be able to reproduce itself. The concept of re-bundling does not, however, imply that regional crises are overcome through regional assets alone (Bathelt and Boggs 2003). Re-bundling processes are likely to be 
initiated or supported by external agents and their competencies. As has been recognised in recent years, integration into global production networks is often essential to the competitiveness of regional actors (Owen-Smith and Powell 2004; Amin 2004). In order to successfully anchor these initiatives within a region and trigger regional development, local actors will, however, also have to be mobilised and drawn into networks. As demonstrated in the following sections, this was a particularly challenging task in the case of the East German chemical industry.

If local anchoring does not take place, it becomes less likely that growth impulses, which could result from investments and access to new markets, will lead to positive regional outcomes. Especially if local networks are underdeveloped, substantial transfers of knowledge and growth impulses from transaction linkages cannot be expected. A regional configuration that develops without embedded ties and regional transaction networks bears the risk of developing into a "hollow cluster" (Bathelt et al. 2004). Hollow clusters are characterised by relatively little coherence and internal cooperation, despite the existence of an agglomeration of firms. Although firms may have strong linkages with transaction partners at a global scale, they lack the ability to transform the knowledge acquired through these "pipelines" into wider regional growth impulses. They might not engage in regional networking and active knowledge exchange, creating what could be referred to as a "low-buzz environment". As a consequence, local firms could remain relatively isolated from one another and lose their joint technology focus and potential for cooperation. Moreover, they might not recognize the need to develop local ties and ground their activities within the local context, especially if their focus is on cross-regional intra-firm ties and liabilities.

The above conceptualisation provides a useful framework for analysing the three cases which follow. In exploring the re-bundling activities that have taken place in the East German chemical industry since reunification, particular emphasis is placed on the investment activities of 
large multinational chemical firms and the government support associated with the funding of private-sector investments. This provides the institutional basis for re-bundling. To evaluate these re-bundling activities, the present structure of local chemical operations in the three regions is summarised in terms of local producer-user linkages, ${ }^{4}$ the diversity of corporate functions, and decision-making competencies. This provides the basis for drawing conclusions regarding the potential cluster structure and the possibility of self-sustaining growth in the future. In the next section, a brief review of the evolution of the chemical industry will be presented to demonstrate how "systemic lock-in" under the specific conditions of the industry led to a system of production regions with strong internal vertical production linkages and limited cross-regional horizontal relationships.

\section{Institutional Transformations: Growth and Transformation of the East}

\section{German Chemical Industry before and after World War II}

In comparison with the situation in West Germany, favourable conditions for the establishment of the chemical industry in East Germany developed relatively late. Major chemical firms were founded as branch operations of West German firms during the 1920s and 1930s in the Halle-Leipzig region (Chemie AG Bitterfeld-Wolfen 1993; Dühr 1998). In 1915, the Leuna works were founded near Halle as a subsidiary of BASF. BASF established large operations for the production of ammonia and methanol, which were extended during the 1920s into a large integrated site of chemical production. Choice of location within the region benefited from the availability of water from the rivers Saale and Mulde, and raw materials such as potassium salt. The most important factor was, however, proximity to major brown coal deposits which were exploited for the production of electrical power at a low cost (Richter 1987). By the late 19th century, brown coal was mined in the Bitterfeld area, which attracted energy-intensive 
chemical production. In the 1890s, both the Chemische Fabrik Griesheim and a subsidiary of the Allgemeine Elektrizitätsgesellschaft (AEG) established operations in Bitterfeld for the production of chlorine (Hackenholz 2004).

In the 20th century, chemical production in East Germany also became strategically important from a defence perspective because it was assumed that these locations would be too far away from Great Britain to be the destination of potential bomber attacks, and therefore relatively safe (Richter 1987; Derlien et al. 1999). The Halle-Leipzig region experienced further growth spurts after the German chemical industry merged into the IG Farben in the 1920s. Chemical production became even more important after the Nazis took over power in 1933 . In 1936, the Buna works were founded in Schkopau, close to Leuna. To reduce Germany's dependence on raw material imports, the Buna facilities began to produce synthetic rubber. This was used as a raw material for the production of tires and developed into an important asset of the Nazi war plans (Hayes 1987; Stinglwagner 1987; Chemie AG Bitterfeld-Wolfen 1993). Both the Leuna and Buna works experienced strong growth processes before and during World War II. By the end of World War II, more than half of the German production of chlorine and ammonia and over $80 \%$ of synthetic rubber originated from within the Halle-Leipzig region (Hackenholz 2004; Wolf 2006)

After World War II, the evolution of the industry was strongly influenced by forced integration into a Soviet-style planned political economy, and corresponding institutions and power structures. The chemical firms in East Germany were occupied by Soviet troops; substantial parts were disassembled; and the remaining operations transformed into Sowjetische Aktiengesellschaften (Soviet-controlled collective firms). Chemical production was completely restructured in accordance with the planning principles of the former Soviet Union. Firms were combined into large state-directed monopoly organisations - that is, first into Volkseigene 
Betriebe or people-owned firms, and later into Kombinate. With the introduction of the government's first comprehensive program for the development of the chemical industry in 1958, the chemical industry was given high priority within national investment plans (Haase 1984; Richter 1987; Chemie AG Bitterfeld-Wolfen 1993). Under the slogan "chemicals give bread, wealth and beauty" the expectation was that the chemical industry would develop into a growth engine for post-World War II reconstruction and future economic growth. The chemical program had two major impacts on the development of the industry. First, those production capacities that were based on coal were substantially expanded. This was part of the national government's strategy to develop an economy that did not strongly depend on energy imports from outside the Comecon hemisphere. Second, investments were also directed towards new oil-based projects with the goal of building up a petrochemical industry based on oil and gas imports from the Soviet Union (Topel 1984; Stinglwagner 1987).

Overall, the industry's evolution under the influence of a Soviet-style planned economy and withdrawal from wider international markets led to the formation of chemical industry regions that were dominated by centrally-controlled vertically-integrated production networks in technologically-obsolete Kombinate. The prevailing investment patterns supported the development of agglomerations of chemical production in the southern half of East Germany, building upon pre-World War II developments (Figure 1). The tendency to rely on brown coal as the main energy source became even stronger after the oil crises of the 1970s when prices for energy imports from the former Soviet Union increased substantially. In 1979, Erich Honecker, the East German leader at that time, demanded that coal-based energy production and technologies are intensified to replace imports of oil and gas (Schwartau 1980). As a consequence, coal-based operations were intensified in technologically-obsolete pre-World War II facilities, without substantial modernisation investments (Karlsch and Stokes 2000). In 1988, 
between 310,000 and 340,000 people were employed by 15 Kombinate in the East German chemical industry, plus an additional 20,000 employees in firms that were not integrated in a Kombinat (Schwartau 1989). ${ }^{5}$ Almost half of these people were employed by six Kombinate in the greater Halle-Leipzig-Wittenberg region (Figure 1). The locations investigated in this paper are Leuna (30,000 employees), Schkopau (30,000 employees) including Böhlen, Bitterfeld (30,000 employees) and Wolfen (21,000 employees). Due to severe economic, political and environmental problems, substantial restructuring became necessary after the reunification. The following section provides an analysis of the respective re-bundling processes around core investment activities from outside the region and the development of potential cluster structures, focussing on producer-user relations, research and development activities, and decision-making structures.

Insert Figure 1 about here

\section{Restructuring Processes and Re-bundling Initiatives after Reunification}

Industrial practices in the German Democratic Republic put enormous stress on the environmental and economic assets in the core regions of the chemical industry. Drastic exploitation of natural resources, under-investment in manufacturing and the reliance on inefficient technologies generated an industrial structure that was suffering from many problems (Bathelt 1995). Based on the availability of brown coal, the chemical industry regions had set up power plants, which generated massive emissions. Outdated technologies were exploited under great economic pressure, causing poor air and water quality, as well as health problems among the population (Schwartau 1987; Spiegel 1990; Chemie AG Bitterfeld-Wolfen 1993; Dühr 1998; 
Karlsch and Stokes 2000). Some authors estimate that, at the time of reunification, a third of the manufacturing plants were older than 50 years and had already been used during or prior to World War II (Faupel et al. 2001). As in other manufacturing industries, chemical production was also characterised by a combination of over-employment and the use of inefficient technologies, thus creating high production costs and low productivity growth. Furthermore, the industry was characterised by an over-representation of basic chemicals and other mass products for which over-capacities already existed in the world marketplace. The variety of specialty chemicals and quality of consumer products was relatively low. Additionally, the lack of marketing competencies and the loss of traditional export markets in Eastern Europe resulted in a situation where most firms could not survive on their own. The evolution of the industry under the constraints of the post-World War II planned economy had thus produced various technological and functional lock-in situations (Grabher 1993), related to wider systemic lock-in.

As a consequence of these problems, most chemical firms in East Germany were not able to gain international competitiveness and had to undergo radical restructuring after reunification (Schmidt 1997). To overcome these lock-in situations, new competencies had to be created to replace those that were destroyed in the restructuring processes that followed. Plants with obsolete and environmentally harmful production were shut down. Most other plants had to reduce production and employment to a minimum. The number of employees in the chemical industry decreased from about 310,000 employees in 1989 (not including petrochemical production, chemical engineering and potash mining) to only 125,000 and 40,000 people in 1991 and 1994, respectively (Verband der Chemischen Industrie 1995). By 2005, employment levels had stabilised, albeit at a low level of 45,000 employees (Table 1). More than $85 \%$ of the original jobs in the East German chemical industry were eliminated following reunification. The impacts of economic restructuring were particularly severe in the traditional core regions around 
Halle-Leipzig. By 2005, only 22,500 of the previous 150,000 jobs still existed in the chemical industry of Sachsen and Sachsen-Anhalt. The effects of this restructuring were quite drastic, in part because the industry had to face a double transition related to both the transformation of the political and economic system, and the Fordist crisis which was strongly associated with ongoing globalisation processes (Kollmorgen 2005; Land 2006).

$* * * * * * * * * * * * * * * * * * * * * * * * * * * * * * * * * *$

Insert Table 1 about here

The re-bundling processes that took place after reunification were initiated by the combined efforts and policies of the federal and Länder governments, aimed at securing existing jobs and creating new ones in competitive economic contexts. Restructuring was led by the Treuhandanstalt, a trust agency that was established in 1990 by the federal government. This agency was originally set up to initiate restructuring processes in the best interest of the general public but quickly shifted into an organisation primarily dealing with privatisation processes through discrete bargaining (Derlien et al. 1999; Roesler 2003). The original goals, which prioritised a reconstruction of the Kombinate over splitting them up and selling divisions separately, were revised and a strategy of partial privatisation applied instead. The aim of this strategy was to maintain the core operations of chemical production, sell individual plants to private investors, modernise the infrastructure of the industry and stimulate new investments (Bundesanstalt für vereinigungsbedingte Sonderaufgaben 1997; Dühr 1998). The result of this policy was that existing value chains were disconnected, leaving truncated networks behind (Albach 1993). Instead of modernising existing production activities by introducing new environmentally-friendly technologies, many operations were closed. 
Parallel to this restructuring, incentives for new investments and modernisation were established in a program called Aufbau Ost (reconstruction of the East). This program was combined with the centralised economic support policy in Germany, that is, the joint task for the improvement of regional economies. In this program, the economic support policies of the federal and Länder governments were combined in an effort to spur redevelopment. The joint task provided funds for economic restructuring and the modernisation of export-related businesses, in an effort to stabilise the labour market and improve the business infrastructure. At this stage, major economic decisions were made in a centralised manner in close coordination with the Treuhandanstalt without additional systematic influence at the Länder level. ${ }^{6}$ The result of this policy was that massive subsidies were granted to the investment projects of West German and foreign chemical firms in East Germany. In the regions studied, up to $50 \%$ of the investment costs in small and medium-sized firms (35\% in the case of large firms), that were aimed at securing or expanding the number of jobs, were paid for through this economic support program (Deutscher Bundestag 2005). Despite these incentives, re-bundling activities in the East German chemical industry remained limited in terms of acquisitions and new investments.

In the following subsections, the nature of these re-bundling activities is investigated in three important chemical industry regions in Sachsen-Anhalt (Table 2). It is shown that processes of reconfiguring existing competencies, mobilising additional resources and engaging external investors were not able to produce economically self-sustained industry clusters. In fact, by analysing the resulting regional producer-user linkages, research and development activities and decision-making competencies evidence is provided that this re-bundling resulted in the establishment of hollow clusters.

Insert Table 2 about here 


\subsection{Leuna}

Parts of the former Leuna works were split up after reunification and sold separately. The re-bundling process remained slow, however, as it was difficult to find external investors. An early example was Linde from west Germany which acquired existing operations in the area of air separation in 1990 to produce industrial gases. These operations were consequently modernised and new facilities built, creating a total of more than 300 jobs (Frankfurter Rundschau 1998; Linde AG 1998). By 1994, Linde's operations were already linked to approximately 150 firms in Leuna and the Bitterfeld-Wolfen area, establishing a network of material flows through pipelines. This was an exception, however, as other new operations did not develop strong regional linkages.

The most important investment in Leuna was the construction of a new oil refinery by a German-French-Russian joint venture of the firms Thyssen Handelsunion, Elf Aquitaine (today: Total Fina Elf) and Rosneft. Along with this investment, Elf acquired the profitable East German Minol network of gas stations. The Leuna investment of more than Euro 2.5 billion (CAD 3.6 billion), which built upon the tradition of petrochemical production at this site, was completed in 1997. Approximately 550 people were employed by the refinery, which was renamed Total Raffinerie Mitteldeutschland in 2003. Employment was much lower, however, than what was originally agreed upon (Frankfurter Rundschau 1997).

This investment had a high priority in the privatisation plans of the Treuhandanstalt because it was considered vital for the re-bundling process of the entire East German chemical industry. As a consequence, the project received subsidies of Euro 0.65 billion (CAD 0.95 billion) (Denecke 1994; Frankfurter Rundschau 1994b). This was heavily criticised by the public since 
the project seemingly mingled with cases of corruption (Hertle 2001; Ginzel and Krauthaar 2006). The total of federal and Länder subsidies and clean-up costs in Leuna were estimated to be as high as Euro 2.8 billion (CAD 4.1 billion). In 1998, a mere 2,500 jobs were left in about 20 chemical firms in the former Leuna works (Wüllenweber 1998). The wider regional workforce related to chemical operations, including supplies and services, was higher, with a total of 9,000 jobs often cited. According to my empirical research, this estimate appears somewhat inflated, however (TOTAL Deutschland GmbH 2004; InfraLeuna, Infrastruktur und Service GmbH 2006). In contrast to the Bitterfeld-Wolfen region, it was possible to preserve the Leuna works as an integrated, relatively closed site of chemical production with InfraLeuna as a joint provider of services. InfraLeuna, established in 1996, was responsible for the provision of security and emergency services, utilities, waste management and other services (Oelke 1998; InfraLeuna, Infrastruktur und Service GmbH 2006). This institutional setting was viewed as being wellsuited for new start-ups and safer than open chemical parks in terms of environmental and health risks. It was expected that this set-up would enable the provision of key services for new firms at low cost. Despite these favourable conditions, the chemical complex had only limited success in attracting new firms. As in other chemical regions, it was only possible to privatise selected production activities; aside from a few larger operations, mainly small and medium-sized firms were established, some of which were closely linked to, or partially owned by, Elf, such as Steag's power plant and Elf Atochem.

Overall, the re-bundling process led to a situation with relatively weak local producer-user relations. To the extent that such relationships developed, they were relatively standardized; some were based on ownership linkages and did not develop extensive knowledge flows. The new activities primarily focussed on production activities and did not invest into research 
facilities. Local decision-making competencies thus remained very limited, focussing on maintaining a continuous production flow.

\subsection{Schkopau (Buna) and Böhlen}

Aside from its importance in the production of synthetic rubber, the former Buna works evolved into a central location for carbide chemistry in the post-World War II period and were characterised by a number of environmentally problematic carbide ovens (Karlsch and Stokes 2000). This explains in part why it remained unclear for a long time whether any re-bundling activities would take place after reunification and whether it would be possible to maintain chemical production at this location. West German chemical firms had already chosen other locations for their primary investments in East Germany and Treuhandanstalt did not actively approach other potential buyers from abroad at this stage.

It was not until 1995, when the US producer Dow Chemical decided to take over the remains of the former Kombinat that a solution materialised. This re-bundling occurred in a combined acquisition that also included polyolefin production in Leuna, underground storage caverns in Teutschenthal, and related operations in Böhlen near the brown-coal mine Lippendorf, about $15 \mathrm{~km}$ south of Leipzig (Buna SOW Leuna Olefinverbund 1998). The goal of this acquisition was to establish a larger industrial complex for the production of synthetic materials: the BSL Olefinverbund. This investment was very important for the East German chemical industry and became the foundation for the establishment of basic linkages between different locations (Faupel et al. 2001). The underlying goal was to stimulate wider re-bundling processes and create a network of producer-user linkages between different regions. In Böhlen, a cracker was built which produced ethylene, propylene and other basic products to be further processed in petrochemical and synthetic materials production in Leuna and Schkopau. The cracker operated 
based on electrical power from a near-by brown-coal power station, as well as Naphtha imports through a pipeline from Rostock at the Baltic Sea.

Dow Chemical only agreed to this deal after the federal and Länder governments agreed upon taking over a large part of the investment and sequel costs of about Euro 5.0 billion (CAD 7.3 billion). Overall, the company created a total of 2,250 permanent jobs in chemical production and an estimated 1,000 jobs in the supplier sector through multiplier effects (Frankfurter Rundschau 1995a; 1995b; Frankfurter Allgemeine Zeitung 2001). When the contract with Dow Chemical became known to the public, heavy criticism arose regarding the relatively small number of jobs secured through this investment.

With a large part of the territory of the former Buna works remaining unused waste land, the decision was later made to open up the area for investments from other firms, preferably those linked with the BSL Olefinverbund through material linkages. In 1998, the so-called "ValuePark" was established, which attracted 13 small and medium-sized firms that further process products from BSL Olefinverbund. These firms added a total of about 300 jobs to the regional labour market (Oelke 1998; Handelsblatt 1999; United Nations Environmental Program 2001).

Despite the integration of the Schkopau activities into wider cross-regional chemical transaction networks in East Germany and the establishment of local ties through the attraction of firms inside the former Buna works, the local effects of re-bundling activities remained limited. Although some producer-user linkages resulted they were not innovative in character and did not require extensive knowledge transfers and problem solving. In addition, only limited development facilities were established, and decision-making competencies focussed on running the local operations. Decisions regarding new products, customers and suppliers were largely made at the corporate level outside the region. Although the linkages that developed were 
important for the development of the overall industry, they were very basic in nature and fully standardised. They concentrated on raw material flows through pipelines and sales relationships between the firms involved. Overall, this did not provide the basis for the development of a fully-fledged industry cluster.

\subsection{Bitterfeld-Wolfen}

In the two former Kombinate in Bitterfeld and Wolfen, re-bundling activities were also difficult because of severe environmental problems and outdated production technologies. In contrast to other East German chemical industry locations, Bitterfeld was traditionally characterised by an extremely diversified portfolio of basic and specialty chemicals, often referred to formerly as the "pharmacy of the German Democratic Republic". As one observer suggested in the mid 1990s, the region still appeared like a patchwork blanket, hosting a number of fairly unrelated chemical production operations (Becker 1995). Due to barriers surrounding privatisation, the question of how the former Kombinate of the region could be organised in the future was unclear for a long time. Initial ideas for re-bundling did not translate into investments that might have created a bandwagon effect.

The original idea of establishing a closed, integrated chemical territory with unified governance, control and service provision, similar to that in Leuna, which was favoured by insiders such as Günter Langner who was initially involved in the management of the chemical park, was not marketable to potential investors and thus had to be abandoned (Mitteldeutsche Zeitung 1999). ${ }^{7}$ After several changes in organisation, the chemical park was privatised in 2001 and transformed into the P-D ChemiePark Bitterfeld Wolfen GmbH, in the form of an openly structured chemical industry park. The Preiss-Daimler group took over the provision of services for the firms (P-D ChemiePark Bitterfeld Wolfen GmbH 2002; http://www.chemiepark.de, date 
accessed March 13, 2007). Although this was a more costly solution from the perspective of small or medium-sized firms, as some interviewees suggested, it probably did not deter additional investments, which were relatively rare to begin with. As such, the conditions for re-bundling worsened in the 1990s.

The most important investment in the post-reunification stage was the decision made by Bayer to establish production in the region (Oelke 1998). This decision and subsequent investment activities served to jump-start further re-bundling in terms of the investment activities of multinational chemical firms. Bayer always emphasised the important role of the former German Chancellor Helmut Kohl and his direct involvement in this decision, arguing that there was no need to establish such a location for market reasons alone. As a result, three specialised plants were set up in the areas of pharmaceuticals, methylcellulose, and resins, followed by the establishment of a fourth plant in the area of ion exchange a few years later. These plants operated largely independently from one another with no internal material linkages. One observer mentioned that these investments could have easily taken place elsewhere if reunification had not changed the investment priorities of the firm. The projects were nonetheless profitable due to low labour costs, longer production runs compared to West Germany, and substantial subsidies through the Aufbau Ost program. In total, 500 new jobs were created by Bayer Bitterfeld during the early 1990s (Kaiser 1994; Becker 1995). Even though these facilities did not develop close ties to the region in terms of input-output flows, and despite the lack of on-site research and distribution, these investments were of key importance because they served to raise the self-confidence of the local people and improved the image of the region. Regional planners referred to Bayer Bitterfeld as an example of an anchor investment to advertise the qualities of the region to other potential investors. Initial reservations regarding the Bitterfeld location were, however, obvious in Bayer's decision to establish its new facilities just outside the 
highly contaminated territory of the former Kombinat. ${ }^{8}$ The firm thus maintained an independent status from the chemical industry park.

In general, decisions regarding supplier linkages and distribution channels of many new firms were made through their respective corporate hierarchies. Furthermore, the region also lost most of its research and development basis which used to be strong (Dühr 1998). Even though the privatisation activities were slow, German and foreign investors gradually established small or medium-sized branches in the region. None of these facilities was able to add a substantial number of jobs to the regional economy to offset the jobs that were previously cut. Some firms acquired larger territories in the region in order to have enough space available for further expansion at a later point; however, these projections turned out to be too optimistic. When Bayer split off its industrial chemicals division into the new firm Lanxess in 2005, it decided to establish its own small chemical industry park to attract further investments from other firms, placing itself in direct competition with the Preiss-Daimler group. Although the labour force had grown to almost 800 people at that point, it had become clear that further investments of Bayer or Lanxess would be unlikely (http://www.bitterfeld.bayer.de, date accessed March 12, 2007). Similarly, the initial growth of Heraeus in the area of quartz glass production stopped after the turn of the Millennium when demand from the US telecommunications industry declined. Further investments had to be postponed and the number of employees was reduced to about 450 (Frankfurter Rundschau 2001). In general, it became clear that further expansion of the chemical industry was unlikely and that reconstruction had come to a standstill. It also turned out that some of the facilities established, such as a new modern sewage plant, were oversized based on unrealistic growth projections in early restructuring stages.

In Wolfen, re-bundling proved to be equally difficult; attempts to provide a longer-term perspective for the former production of photo-chemicals and film-packs failed (Frankfurter 
Rundschau 1994a; Chemie-Produktion 1996; Dühr 1998). This was not undisputed, however; some media reports argued that these facilities could have been saved due to their specialised competencies if a specialist in the field had made a move to acquire and restructure them. In total, only bits and pieces of the former activities were able to survive, among them the management buy-out Organica. ${ }^{9}$ In one of the main buildings of the Filmfabrik Wolfen, a technology and incubator facility was founded in 1992: the TGZ Technologie- und Gründerzentrum BitterfeldWolfen $\mathrm{GmbH}$. By providing office and laboratory space of about $9,000 \mathrm{~m}^{2}$ and start-up support, the TGZ aimed to stimulate new firm formation. Since the late 1990 s, the facility became the site of about a dozen small start-ups in areas related to chemical production, such as biotechnology and environmental technology (http://www.tgz-chemie.de, date accessed March 12, 2007). Although these firms had only a few linkages with the traditional regional production core, they were successful and survived. Their overall contribution to job growth in the region was, however, not significant.

An important prerequisite for the reconstruction of the chemical industry in the region was the preservation of at least some moderate material linkages between chemical firms based on chlorine production. It took several years until it was possible to stabilise these linkages since potential investors for the chlorine production plant were not available. The chlorine plant was finally acquired and reconstructed in 1997 by ECI Electro-Chemie Ibbenbühren from West Germany. Since then, the firm attained about 60 regional customers and became the key supplier of a cycle of material flows that involved half a dozen firms supplying hydrochloric acid, technical gases, silicon tetrachloride and related products to the production of quartz glass (Derlien et al. 1999; Schmid 2000). Overall, employment in the chemical industry remained modest. By 2002, a total of Euro 2.7 billion (CAD 3.9 billion) had been invested in the reconstruction of the chemical park Bitterfeld-Wolfen. The park had a size of $12.4 \mathrm{~km}^{2}$ and 
hosted about 50 chemical and 300 other firms with a workforce of merely 3,000 and 6,500 people, respectively.

Although some producer-user relations developed in Bitterfeld-Wolfen around the production of chlorine and quartz glass, too few firms were left to be able to establish a closely interrelated production network. Regional supplier relations were limited, and a large proportion of overall production was exported to other countries. Numerous interviewees said that direct supplier and customer contact was only made at the corporate level outside the region. Local decision-making competencies often remained limited. There were few exceptions to this trend though some smaller firms had relocated production and decision-making to the region.

\section{Conclusions: Toward the Diversification of Hollow Clusters?}

This paper clearly illustrates that the East German chemical industry had to overcome drastic ruptures both after World War II and the reunification, which were associated with changes in the political and economic system and necessitated radical re-bundling activities. The restructuring processes put tremendous pressure on existing firms and their workforce. In contrast with the suggestion of Faupel et al. (2001) who evaluate these processes in the HalleLeipzig region very positively and suggest that the region has substantial growth potential in the future, this study does not share such optimistic predictions. The initial expectation that East German regions would only require a short-term trigger to develop self-sustaining growth seems ill-founded as total employment and sales have remained at a low level. This paper argues that while an evolutionary perspective drawing on lock-in processes is important in understanding this development, it is insufficient in explaining the shifts that occurred in recent years. The concepts of re-bundling and hollow clusters are thus employed to provide a better understanding of the restructuring processes and their consequences. 
The overall development of the industry should not simply be evaluated as a failure. Rather, it may be viewed as, at least, a partial success given that the prospects for the growth of chemical production in the new Länder were unclear at the time of reunification. The re-bundling activities began with mass closures of production facilities and forced disintegration of the former Kombinate. Later, this led to new investments by multinational firms from West Germany and other capitalist countries. The number of employees in the East German chemical industry consequently increased by more than 5,000 (13.5\%) to a total of 45,000 people between 2000 and 2005 (Table 1), while other manufacturing sectors continued to decline or stagnate (Thomas 2005). The fact that sales figures also grew substantially since the mid 1990s also indicates that modern production structures were established (Verband der Chemischen Industrie 2006; Derlien et al. 1999). This paper views the restructuring that took place as an example of re-bundling (Bathelt and Boggs 2003). As shown above, these processes were able to mobilise internal and external capital for new projects. This is remarkable because there was no need for excessive expansion of chemical production after reunification. Most of the demand for chemicals in East Germany could easily have been supplied through existing production capacities at other locations.

Despite this, federal and Länder policies failed to stimulate self-sustaining growth in strong industry clusters and networks (Thomas 2005). The overall prospects for growth in the East German chemical industry are therefore limited. This can be attributed to a number of factors. First, the chemical industry in Germany stagnated since the 1980s, and employment gradually declined due to globalisation (Bathelt 1995; Chapman and Edmond 2000). From 1995 to 2005, the number of employees in Germany decreased by $12.2 \%$ to a mere 470,000 people (Table 1 ); major start-up or relocation processes cannot be expected under these conditions. Second, restructuring did not create fully-fledged industry clusters. Although the regional economies are 
well-linked to West Germany and international markets through corporate ties of multinational firms, regional networks - that could provide the basis for learning, knowledge creation and innovation - remained weak. ${ }^{10}$ Instead, hollow clusters resulted which were strongly outwardlooking with little internal "glue", similar to the structure described by Bathelt et al. (2004). ${ }^{11}$ The chemical industry regions investigated were composed of a relatively small number of chemical firms which operated in specialised segments of the industry, providing little potential for regional networking and innovation. Similar to the findings of Land (2006), different types of firms can be identified in these regional economies, which contribute to further segmentation (see, also, Schmidt 1997; Kollmorgen 2005); however, these firms are unlikely to form a basis for strong regional networks in the future. Overall, the re-deployment of resources and competencies to other sectors and/or activities did not provide broad economic triggers in either of the regions investigated (Table 2). Federal in combination with Länder policies of economic support were not able to translate intra- and inter-sectoral linkages into economically sustainable and dynamic industry clusters.

In conclusion, it is unlikely that the development of the chemical industry in East Germany will lead to substantial increases in regional employment and sales in the near future. In realising the limited growth prospects, the regions began to develop policies that acknowledge this trend and envision alternative perspectives. They adapted new goals aside from supporting the chemical industry. In Bitterfeld, for instance, the Goetsche, a large former brown-coal mine, was flooded and huge effort put into the development of a recreational area focussed on water and fun activities. Along with this, the historical city core was reconstructed and landfill sites cleaned up to make the region more attractive both for locals to stay and visitors to come. Similar developments were also underway in the Halle, Leipzig and Niederlausitz regions to create a new tourism industry. In addition, other industries were supported, such as the automobile supplier 
and solar cell industries. These efforts were able to compensate for ongoing job losses in the chemical industry. As a result of these trends, political and economic leaders are seemingly moving closer to one another, providing the basis for the establishment of regional political networks in the future. These networks may become the basis of multiple regional industry networks in the long term which are not necessarily focussed exclusively on chemical production.

\section{Acknowledgements}

This paper was prepared for the 2007 conference "Between Past and Future: East Germany Before and After 1989" in Toronto, organised by the Joint Initiative in German and European Studies at the University of Toronto. I would like to thank the participants of this conference, particularly Stefan Haas, Raj Kollmorgen, Jeff Kopstein, Charles Maier and Jonathan Zatlin, for supportive feedback. I am also very grateful for the supportive comments received from two reviewers and the EURS Editors which helped sharpen the argument presented. Thanks are also due to those executives, managers and local experts in East Germany who participated in this research over many years. Furthermore, I owe special thanks to Ute Hirsch and Günter Langner for their ongoing support in organising my research and making connections with key individuals, and to Rachael Gibson, Nicole Kogler and Clare Wiseman for commenting on earlier versions of this paper.

\section{References}

Albach, H. (1993): Zerrissene Netze: Eine Netzwerkanalyse des ostdeutschen Transformationsprozesses (Ruptured Networks: A Network Analysis of East German Transformation). Berlin: Edition Sigma - Bohn.

Amin, A. (2004): Regions unbound: towards a new politics of place. Geografiska Annaler 86 B: $33-44$ 
Arthur, W. B. (1988): Competing technologies: an overview. In: Dosi, G., Freeman, C., Nelson, R. R., Silverberg, G. and Soete, L. L. G. (Eds.): Technical Change and Economic Theory. London, New York: Pinter, pp. 590-607.

Bathelt, H. (1995): Global competition, international trade and regional concentration: the case of the German chemical industry during the 1980s. Environment and Planning C - Government and Policy 13: 395-424.

Bathelt, H. (2005): Geographies of production: growth regimes in spatial perspective 2 - Knowledge creation and growth in clusters. Progress in Human Geography 29: 204-216.

Bathelt, H. and Boggs, J. S. (2003): Towards a reconceptualisation of regional development paths: is Leipzig's media cluster a continuation of or a rupture with the past? Economic Geography 79: 265-293.

Bathelt, H. and Glückler, J. (2003): Wirtschaftsgeographie: Ökonomische Beziehungen in räumlicher Perspektive (Economic Geography: Economic Relations in Spatial Perspective). 2nd edition. Stuttgart: UTB - Ulmer.

Bathelt, H. and Kappes, K. (2008): Regional deindustrialization and rebundling: evidence from the merger of the former German Hoechst and French Rhône-Poulenc groups. European Planning Studies 16: forthcoming.

Bathelt, H., Malmberg, A. and Maskell, P. (2004): Clusters and knowledge: local buzz, global pipelines and the process of knowledge creation. Progress in Human Geography 28: 31-56. Becker, W. (1995): Chemiepark Bitterfeld ist noch ein Flickenteppich (Chemical park Bitterfeld is still like a patchwork blanket). Frankfurter Rundschau, October 10, p. 15.

Boschma, R. A. and Lambooy, J. G. (1999): Evolutionary economics and economic geography. Journal of Evolutionary Economics 9: 411-429.

Bourdieu, P. (1988): Homo Academicus. Stanford: Stanford University Press. 
Brussig, M. (2000): Nutzung regionaler Potential in Ostdeutschland via Kooperation - eine industriepolitische Option mit Hindernissen (Using regional growth potentials in East Germany through networking). In: Hirsch-Kreinsen, H. and Schulte, A. (Eds.): Standortbindungen: Unternehmen zwischen Globalisierung und Regionalisierung (Locational Ties Between Globalisation and Regionalisation). Berlin: Edition Sigma - Bohn, pp. 129-155.

Buna SOW Leuna Olefinverbund (1998): 1990 - 2000 Milestones. Schkopau.

Bundesanstalt für vereinigungsbedingte Sonderaufgaben (1997): Umstrukturierung der ostdeutschen Großchemie: Der schwierige Weg in die Zukunft (Restructuring of the East German Chemical Industry: Difficult Path into the Future). Berlin: BvS.

Chapman, K. and Edmond, H. (2000): Mergers/acquisitions and restructuring in the EU chemical industry: patterns and implications. Regional Studies 34: 753-767.

Chemie AG Bitterfeld-Wolfen (1993): Bitterfelder Chronik: 100 Jahre Chemiestandort Bitterfeld-Wolfen (The Bitterfeld Chronicle: 100 Years of Chemical Production). Dresden. Chemie-Produktion (1996): Agieren zwischen 'Kolossen' (Acting between giants). (6/96), p. 2425.

David, P. A. (1985): Clio and the economics of QWERTY. American Economic Review, Papers and Proceedings 75: 332-337.

Denecke, M. (1994): Milliarden fürs Revier (Billions for the region). gp magazin, (5/94), p. 15.

Derlien, H., Faupel, T. and Nieters, C. (1999): Industriestandort mit Vorbildfunktion? Das ostdeutsche Chemiedreieck (The East German Chemical Triangle as a Role Model?). Discussion Papers FS IV 99-16. Berlin: Wissenschaftszentrum Berlin für Sozialforschung. Deutscher Bundestag (2005): Vierunddreißigster Rahmenplan der Gemeinschaftsaufgabe “Verbesserung der regionalen Wirtschaftsstruktur” (GA) für den Zeitraum 2005 bis 2008 
(Thirtyfourth Framing Plan of the Joint Economic Support Programme for the 2005 - 2008 Period). Bundestagsdrucksache 15/5141. Berlin.

Dosi, G. (1988): The nature of the innovative process. In: Dosi, G., Freeman, C., Nelson, R. R., Silverberg, G. and Soete, L. L. G. (Eds.): Technical Change and Economic Theory. London, New York: Pinter, pp. 221-238.

Dühr, S. (1998): Nachhaltige Regionalentwicklung als Leitbild für altindustrialisierte Regionen? Die Umstrukturierung von Altindustriestandorten in der Region Bitterfeld-Wolfen (Restructuring of Old Industrial Locations in the Bitterfeld-Wolfen Region). Trier: Zentrum für Europäische Studien, Universität Trier.

Faupel, T., Nieters, C. and Derlien, H. (2001): Chemieparks als innovative Strategie? Analyse des Strukturwandels in der Region Bitterfeld-Wolfen/Schkopau/Leuna (Chemical industry parks as an innovative strategy? Structural change in the BitterfeldWolfen/Schkopau/Leuna region). Geographische Rundschau 53 (3): 31-36.

Feldman, M. and Francis, J. L. (2006): Entrepreneurs as agents in the formation of industrial clusters. In: Asheim, B., Cooke, P. and Martin, R. (Eds.): Clusters and Regional Development: Critical Reflections and Explorations. London, New York: Routledge, pp. $115-136$

Frankfurter Allgemeine Zeitung (2001): Dow Chemical rechnet für BSL mit hohem Wachstum im Osten (Dow Chemical expects high growth of BSL in the East). March 10, p. 24. Frankfurter Rundschau (1994a): Hauri sagt endgültig ab - Belegschaft ist empört (Hauri cancels - Labour force is in anger). May 3, p. 15.

Frankfurter Rundschau (1994b): Kanzler zündet Milliardenprojekt in Leuna (Chancellor starts Leuna project, worth billions). May 26, p. 11. 
Frankfurter Rundschau (1995a): Dow beerbt Plaste und Elaste (Dow inherits Buna). April 7, p. 12.

Frankfurter Rundschau (1995b): Buna-Verkauf lastet schwer auf Bonner Kasse (Buna sale stresses federal budget). May 15, p. 11.

Frankfurter Rundschau (1997): Leuna 2000: Milliardenprojekt erhält Betriebsgenehmigung (Leuna 2000: billion dollar project starts production). July 7, p. 14.

Frankfurter Rundschau (1998): Linde: Raffinerie Leuna erteilt Milliardenauftrag (Linde: billion dollar deal with the Leuna refinery). February 26, p. 14.

Frankfurter Rundschau (2001): Rückzieher aus Bitterfeld (Backdown from Bitterfeld). November 5, p. 10.

Fritsch, M., Meyer-Krahmer, F. and Pleschak, F. (Eds.) (1998): Innovationen in Ostdeutschland: Potentiale und Probleme (Innovation Processes in East Germany: Potentials and Problems). Heidelberg: Physica.

Ginzel, A. and Kraushaar, M. (2006): Absahner in Osten (Free riders in the East). Die Zeit, November 9.

Grabher, G. (1993): The weakness of strong ties: the lock-in of regional development in the Ruhr area. In: Grabher, G. (Ed.): The Embedded Firm: On the Socioeconomics of Industrial Networks. London, New York: Routledge, pp. 255-277.

Grabher, G. (1996): Neue Bundesländer? Zur Rolle des historischen Erbes in der Reorganisation von Betrieben und Regionen in Brandenburg (Reorganization of Firms in Brandenburg, East Germany). Discussion Papers FS I 96-104. Berlin: Wissenschaftszentrum Berlin für Sozialforschung.

Haase, H. E. (1984): Die Wirtschaft der DDR (The economy of the German Democratic Republic). Geographische Rundschau 36 (12): 632-638. 
Hackenholz, D. (2004): Die elektrochemischen Werke in Bitterfeld 1914-1945: Ein Standort der IG-Farbenindustrie AG (The Electrochemical Works in Bitterfeld 1914-1945: A Location of the IG-Farben). Münster: Lit.

Handelsblatt (1999): Olefinverbund verfehlt Umsatzziel für 1998 (BSL does not meet 1998 performance goals). (41), p. 16.

Hassink, R. (2005): How to unlock regional economies from path dependency? From learning region to learning cluster. European Planning Studies 13: 521-535.

Hayes, P. (1987): Industry and Ideology: IG Farben in the Nazi Era. Cambridge, MA, New York, New Rochelle: Cambridge University Press.

Hertle, H.-H. (2001): Der kostspielige Leuna-Deal (Tue costly Leuna deal). Frankfurter Rundschau, February 3, p. 17.

InfraLeuna, Infrastruktur und Service GmbH (2006): Chemiestandort Leuna: sie sind herzlich willkommen! (Chemical Location Leuna: You Are Very Welcome!). Leuna.

Kaiser, M. (1994): Weißstorch in Bitterfeld (White storks in Bitterfeld). Frankfurter Rundschau, November 19, p. ZB1.

Karlsch, R. and Stokes, R. (2000): Die Chemie muss stimmen: 1990-2000 Bilanz des Wandels (The Chemistry Has to Work: 1990-2000 Balance of Change). Edited by Buna Sow Leuna Ofelfinverbund GmbH. Leipzig: Edition Leipzig.

Klemmer, P. (1995): Gemeinschaftsaufgabe "Verbesserung der regionalen Wirtschaftsstruktur" (Joint program on the improvement of regional economies). In: Akademie für Raumforschung und Landesplanung (Ed.): Handwörterbuch der Raumordnung (Handbook of Spatial Planning). Hannover: Akademie für Raumordnung und Landesplanung, pp. 395397. 
Kollmorgen, R. (2005): Ostdeutschland: Beobachtungen einer Übergangs- und Teilgesellschaft (East Germany: Observations of a Transitory and Fragmentary Society). Wiesbaden: VS Verlag.

Koschatzky, K. and Zenker, A. (1999): Innovative Regionen in Ostdeutschland - Merkmale, Defizite, Potentiale (Innovative Regions in East Germany - Characteristics, Deficits, Potentials). Working paper Regionalforschung No. 17. Karlsruhe: Fraunhofer-Institut für Systemtechnik und Innovationsforschung.

Land, R. (2006): Fragmentierte Wirtschaftsstrukturen zwischen Deindustrialisierung, Stagnation und Innovation (Fragmented economic structure between deindustrialisation, stagnation and innovation). Berliner Debatte Initial 17 (5): 27-38

Linde AG (1998): The Leuna 2000 Refinery. Leuna

Maillat, D., Lecoq, B., Nemeti, F. and Pfister, M. (1995): Technology district and innovation: the case of the Swiss Jura. Regional Studies 29: 251-263.

Malmberg, A. and Maskell, P. (2002): The elusive concept of localization economies: towards a knowledge-based theory of spatial clustering. Environment and Planning A 34: 429-449.

Martin, R. and Sunley, P. (2006): Path dependence and regional economic evolution. Journal of Economic Geography 6: 35-437.

Merkel, W. (1999): Systemtransformation: Eine Einführung in die Theorie und Empirie der Transformationsforschung (System Transformation: A Theoretical and Empirical Introduction into Transformation Research). Opladen: UTB.

Metze, R. and Schroeckh, J. (1998): Kooperation in Ostdeutschland nach der Wende - von zufälligen Verbunden und gezielten Netzwerken (Cooperation in East Germany after the reunification - unanticipated coalitions and intended networks). In: Metze, R., Mühler, K and Opp, K.-D. (Eds.): Der Transformationsprozess: Analysen und Befunde aus dem 
Leipziger Institut für Soziologie (The Transformation Process in the Research of the Leipzig Institute of Sociology). Leipzig: Leipziger Universitätsverlag, pp. 231-252. Mitteldeutsche Zeitung (1999): Frühlingserwachen mit neuen Aufträgen in alten Anlagen (Spring awakening with new contracts in old plants). February 18.

Nelson, R. R. and Winter, S. G. (1982): An Evolutionary Theory of Economic Change. Cambridge, MA: Harvard University Press.

Oelke, E. (1998): Das Verdichtungsgebiet Halle-Leipzig (The Halle-Leipzig agglomeration). In: Kulke, E. (Ed.): Wirtschaftsgeographie Deutschlands (Economic Geography of Germany). Gotha, Stuttgart: Klett-Perthes, pp. 381-405.

Owen-Smith, J. and Powell, W. W. (2004): Knowledge networks as channels and conduits: the effects of spillovers in the Boston biotechnology community. Organization Science 15: 221.

P-D ChemiePark Bitterfeld Wolfen GmbH (2002): Die Chemie stimmt! ... im Chemiedreieck mitten in Europa (The Chemistry works! ... in the Chemical Industry Triangle in the Middle of Europe). Bitterfeld.

Porter, M. E. (1990): The Competitive Advantage of Nations. New York: Free Press.

Richter, D. (1987): 100 Jahre chemische Großindustrie in Mitteldeutschland (100 years of chemical industry in central Germany). Geographische Rundschau 39 (11): 614-623.

Roesler, J. (2003): Ostdeutsche Wirtschaft im Umbruch 1970 - 2000 (Changes in the East German Economy 1970 - 2000). Bonn: Bundeszentrale für politische Bildung.

Sadler, D., Swain, A. and Hudson, R. (1993): The automobile industry and Eastern Europe: new production strategies or old resolutions? Area 25: 339-349.

Schmid, K.-P. (2000): Phoenix aus dem Russ (Like a Phoenix from the ashes). Die Zeit, September 28, p. 25. 
Schmidt, R. (1997): Viele ostdeutsche Betriebe leiden noch heute unter Phantomschmerzen (Many East German firms suffer from phantom pain). Frankfurter Rundschau, April 11, p. 18.

Schüller, A. (1990): Probleme des Übergangs von der Staatswirtschaft zur Marktwirtschaft (Problems in the shift from state-planned to market economy). In: Marburger Gesellschaft für Ordnungsfragen der Wirtschaft (Eds.): Zur Transformationsforschung von Wirtschaftssystemen: Von der sozialistischen Planwirtschaft zur sozialen Marktwirtschaft (On the Transformation of Economic Systems: From Socialist Planned Economy to Social Market economy). Marburg: MGOW, pp. 1-24.

Schumann, M., Baethge-Kinsky, V., Kuhlmann, C. and Neumann, U. (1994): Trendreport Rationalisierung: Automobilindustrie, Werkzeugmaschinenbau, Chemische Industrie (Trend Report Rationalisation: Automobile Production, Tool Making and Chemical Production). Edition Sigma - Bohn: Berlin.

Schwartau, C. (1980): Die chemische Industrie in der DDR - Renaissance einheimischer Rohstoffe durch Beschränkung der Erdölimporte? (The chemical industry in the German Democratic Republic - Renaissance of national resources due to limitations on oil imports?). Wochenbericht des DIW (47/80): 485-490.

Schwartau, C. (1987): Umweltprobleme in einem alten Industrierevier - der Ballungsraum HalleLeipzig (Environmental problems in an old industrialised region - The agglomeration Halle-Leipzig). Geographische Rundschau 39 (11): 628-632.

Schwartau, C. (1989): Die chemische Industrie in der DDR - Wachstum in konservativen Strukturen (The chemical industry in the German Democratic Republic - Growth in conservative structures). Wochenbericht des DIW (41/89): 498-504. 
Scott, A. J. (1998): Regions and the World Economy: The Coming Shape of Global Production, Competition, and Political Order. Oxford, New York: Oxford University Press.

Setterfield, M. (1993): A model of institutional hysteresis. Journal of Economic Issues 27: 755774.

Spiegel (1990): "Die Leute werden dumm im Kopf" ("The people get dumb in their heads"). (2/1990), pp. 35-46.

Stinglwagner, W. (1987): Energiewirtschaft in der DDR (Energy production in the German Democratic Republic). Geographische Rundschau 39 (11): 635-640.

Storper, M. and Walker, R. (1989): The Capitalist Imperative. Territory, Technology, and Industrial Growth. New York, Oxford: Basil Blackwell.

Thomas, M. (2003): Neue Selbständige in Ostdeutschland - ein soziales Phänomen quer zur Transformationslogik? (New self-employed people in East Germany - A social phenomenon against the transformation logic?). In: Brussig, M., Ettrich, F. and Kollmorgen, R. (Eds.): Konflikt und Konsens: Transformationsprozesse in Ostdeutschland (Conflict and Consensus: Transformation Processes in East Germany). Opladen: Leske + Budrich, pp. 49-80.

Thomas, M. (2005): Ostdeutscher Stillstand versus ungleichzeitige Lernprozesse Transformationsmodus und Innovationsblockaden (Stagnation versus non-simultaneous learning in East German transformation). In: Kollmorgen, R. (Ed.): Transformation als Typ sozialen Wandels: Postsozialistische Lektionen, historische und interkulturelle Vergleiche (Transformation as a Form of Social Change: Post-socialist Lectures and Historical and Inter-cultural Comparisons). Münster: Lit, pp. 95-110.

Topel, T. (1984): Energie- und Industriezentren in der DDR (Energy and industrial centres in the German Democratic Republic). Geographische Rundschau 36 (12): 615-621. 
TOTAL Deutschland GmbH (2004): TOTAL Raffinerie Mitteldeutschland feiert 10-jähriges Jubiläum (10 Year Anniversary of the TOTAL refinery). Press release, September 15. United Nations Environmental Program (2001): ValuePark - A High-Performance Location. Case Study (URL: http://www.uneptie.org/pc/ind-estates/casestudies/ValuePark.htm).

Uzzi, B. (1997): Social structure and competition in interfirm networks: the paradox of embeddedness. Administrative Science Quarterly 42: 35-67.

Verband der Chemischen Industrie (1995): Chemiewirtschaft in Zahlen - Ausgabe 1995 (Chemical Economy in Numbers - 1996 Edition). Frankfurt/Main: Erhardt Verband der Chemischen Industrie (2006): Chemiewirtschaft in Zahlen - Ausgabe 2006 (Chemical Economy in Numbers - 1996 Edition). Frankfurt/Main: Erhardt

Voskamp, U. and Wittke, V. (1990): Aus Modernisierungsblockaden werden Abwärtsspiralen zur Reorganisation von Betrieben und Kombinaten der ehemaligen DDR (From modernisation blockages to downward tendencies - On the reorganisation of state-owned firms in the former G.D.R.). Sofi-Mitteilungen 3:12-30.

Wolf, H. (2006): Regionale Clusterdynamik in der Chemieindustrie: Zur Rolle der Weißen Biotechnologie dargestellt am Beispiel von Nordrhein-Westfalen und Mitteldeutschland (Regional Cluster Dynamics in the Chemical Industry: The Case of White Biotechnology in North Rhine Westphalia and Middle Germany). Unpublished Masters Thesis. Halle: Fakultät für Wirtschaftswissenschaften, Universität Halle-Wittenberg.

Wüllenweber, W. (1998): Blüten-Träume (Flowering dreams). Stern (39), pp. 248-254 
Figure 1. Employment in the Chemical Industry of the Former German Democratic Republic by Location and Kombinat, 1988 (Source: Bathelt 1995, p. 405)

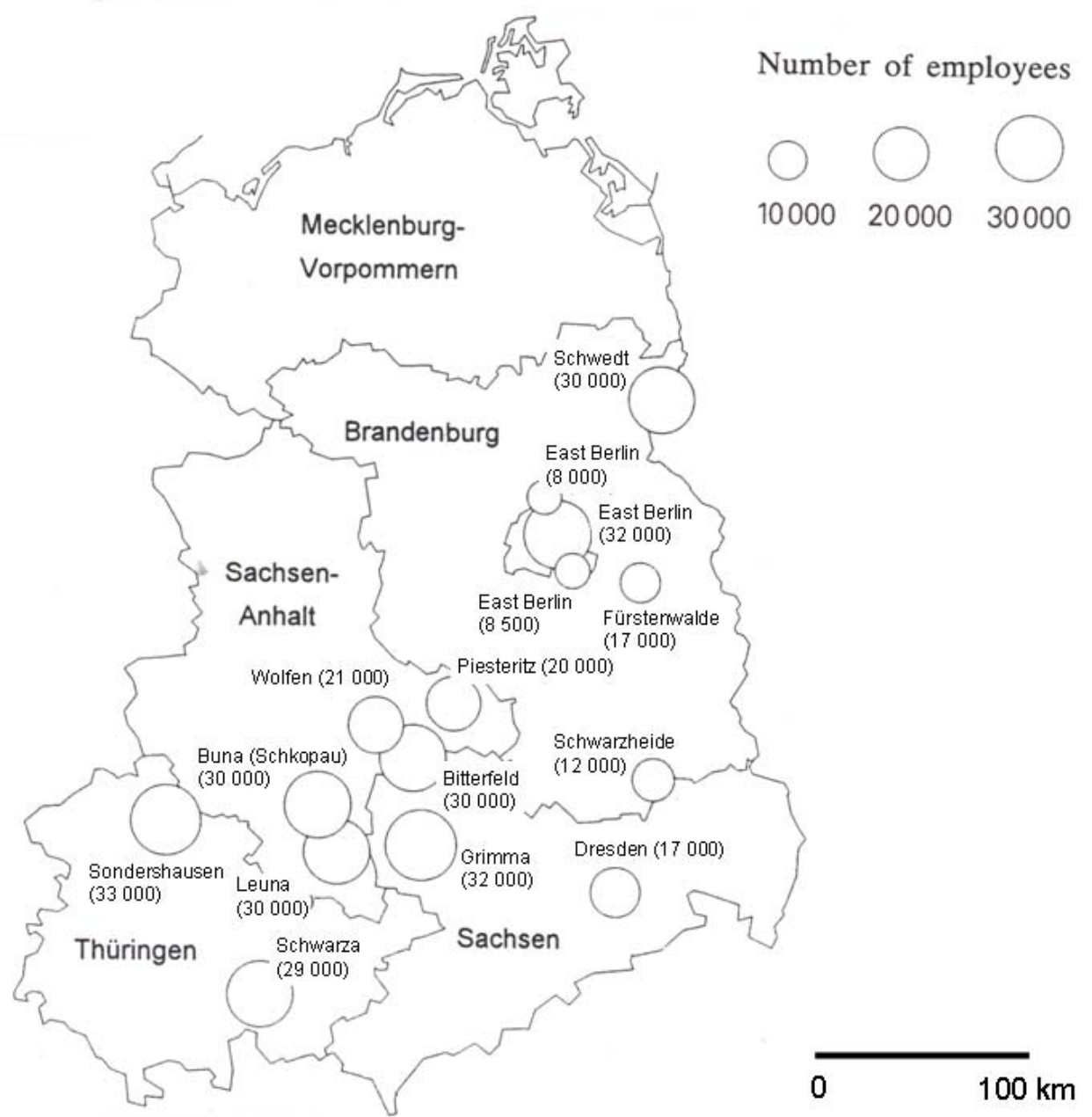


Table 1. Employment in the East German Chemical Industry by Land, 1995-2005 (Source: Verband der Chemischen Industrie 2006, pp. 48 and 56ff.)

\begin{tabular}{lrrr}
\hline & \multicolumn{3}{c}{ Number of employees in the chemical industry } \\
Land & 1995 & 2000 & 2005 \\
\hline Berlin & 12,900 & 9,950 & 11,650 \\
Brandenburg & 5,500 & 5,300 & 4,650 \\
Mecklenburg- & & & \\
Vorpommern & 550 & 850 & 1,150 \\
Sachsen & 7,250 & 8,000 & 9,250 \\
Sachsen-Anhalt & 14,500 & 11,550 & 13,200 \\
Thüringen & 3,550 & 4,050 & 5,150 \\
\hline Total & 44,250 & 39,700 & 45,050 \\
Share of German total & $8.3 \%$ & $8.4 \%$ & $10.2 \%$ \\
German total & 535,900 & 470,300 & 440,800 \\
\hline
\end{tabular}


Table 2. Characteristics of Chemical Production in Leuna, Buna and Bitterfeld-Wolfen (Source: Compiled from interview results and various sources)

\begin{tabular}{|c|c|c|c|}
\hline \multirow[b]{2}{*}{$\begin{array}{l}\text { Production } \\
\text { characteristic }\end{array}$} & \multicolumn{3}{|c|}{ Chemical production structure at } \\
\hline & Former Leuna works & $\begin{array}{l}\text { Former Buna works } \\
\text { (Schkopau) }\end{array}$ & $\begin{array}{l}\text { Former Kombinate in } \\
\text { Bitterfeld and Wolfen }\end{array}$ \\
\hline $\begin{array}{l}\text { - Number of } \\
\text { chemical employees } \\
\text { (a) } 1988 \\
\text { (b) After } 2000 \\
\text { (estimates) }\end{array}$ & $\begin{array}{l}30000 \\
2500\end{array}$ & $\begin{array}{l}30000 \\
2250(+300)\end{array}$ & $\begin{array}{l}51000 \\
3000\end{array}$ \\
\hline $\begin{array}{l}\text { - Number of } \\
\text { chemical firms after } \\
2000 \text { (estimates) }\end{array}$ & 20 & $1(+13)$ & 50 \\
\hline - Firm structure & $\begin{array}{l}\text { Mostly mid-sized } \\
\text { chemical branches; } \\
\text { one large French } \\
\text { multinational branch }\end{array}$ & $\begin{array}{l}\text { One large subsidiary } \\
\text { of US multinational; } \\
\text { few small/mid-sized } \\
\text { firms in supplier } \\
\text { park }\end{array}$ & $\begin{array}{l}\text { Numerous large or mid- } \\
\text { sized branches of mostly } \\
\text { German multinationals; } \\
\text { few MBOs and small start- } \\
\text { ups }\end{array}$ \\
\hline $\begin{array}{l}\text { - Nature of } \\
\text { production }\end{array}$ & $\begin{array}{l}\text { Mixed small-scale } \\
\text { chemical production } \\
\text { around a large oil } \\
\text { refinery }\end{array}$ & $\begin{array}{l}\text { Production of } \\
\text { synthetic materials } \\
\text { (polyolefins) and } \\
\text { few related products }\end{array}$ & $\begin{array}{l}\text { Mixed chemical } \\
\text { production, partially } \\
\text { related to chlorine/quartz } \\
\text { glass }\end{array}$ \\
\hline $\begin{array}{l}\text { - Provision of } \\
\text { support services }\end{array}$ & $\begin{array}{l}\text { Integrated service } \\
\text { provision through } \\
\text { InfraLeuna }\end{array}$ & $\begin{array}{l}\text { Internal service } \\
\text { provision through } \\
\text { US multinational }\end{array}$ & $\begin{array}{l}\text { Disintegrated/decentralised } \\
\text { services }\end{array}$ \\
\hline $\begin{array}{l}\text { - Local/regional } \\
\text { supplier-customer } \\
\text { linkages }\end{array}$ & $\begin{array}{l}\text { Local linkages are } \\
\text { weak; in part related } \\
\text { to ownership } \\
\text { linkages; resources } \\
\text { are mostly imported }\end{array}$ & $\begin{array}{l}\text { Some local intra- } \\
\text { firm linkages; some } \\
\text { regional sales of } \\
\text { polyolefins; exports } \\
\text { through corporate } \\
\text { networks dominate }\end{array}$ & $\begin{array}{l}\text { Some local transaction } \\
\text { linkages around } \\
\text { chlorine/quartz glass; } \\
\text { limited regional supplies; } \\
\text { exports through corporate } \\
\text { networks dominate }\end{array}$ \\
\hline $\begin{array}{l}\text { - Research activities } \\
\text { and knowledge } \\
\text { flows }\end{array}$ & $\begin{array}{l}\text { Weak development } \\
\text { activities; limited } \\
\text { local knowledge } \\
\text { exchange }\end{array}$ & $\begin{array}{l}\text { Limited } \\
\text { development } \\
\text { activities; local intra- } \\
\text { corporate knowledge } \\
\text { flows }\end{array}$ & $\begin{array}{l}\text { Some research and } \\
\text { development; local } \\
\text { communication focuses on } \\
\text { generic knowledge/ } \\
\text { regional support policies }\end{array}$ \\
\hline - Political networks & Limited potential & Limited potential & $\begin{array}{l}\text { Potential for the formation } \\
\text { of wider civic capital/ } \\
\text { networks }\end{array}$ \\
\hline
\end{tabular}




\section{Endnotes}

${ }^{1}$ If possible interviews were recorded on tape and transcribed. Often, it seemed more appropriate, however, to just take interview notes as the firms and interview partners were under a lot of pressure or sceptical with respect to the purposes of this research. To study the actions and strategies, particularly of large dominant firms, is key in understanding the regional restructuring processes and evaluate the prospects for future growth. This is because many established chemical operations were closed down; start-ups remained an exception; and the survival of other operations depended on the engagement of a limited number of multinational chemical firms. The activities of these branches and their performance were extremely important for the overall regional development. Therefore, about half of the interviews were conducted with new branches or subsidiaries of multinational chemical firms. It is believed that the empirical work conducted well reflects the development of the case study regions.

${ }^{2}$ This systemic lock-in, which was related to the wider institutional infrastructure, went beyond the political lock-in characterised by Grabher (1993) through political networks and rigid power relations.

${ }^{3}$ It is well-known, of course, that remnants of old personal networks, often referred to as "Seilschaften" ("rope teams"), were able to survive and existed for a long time. These personal ties had sometimes introduced rigidity into the vertical production networks in the post-World War II period. These structures were found in many sectors, including the automobile, robotics and chemical industries (e.g. Voskamp and Wittke 1990; Sadler et al. 1993; Dühr 1998). In the interviews conducted, this was often confirmed. It had sometimes (but not always) negative effects on political decision-making and the ability to mobilise people for action.

${ }^{4}$ When discussing regional networks of the chemical industry, we have to consider that the structure of producer-user relations differs from that in many other industries in terms of their intensity. Therefore, our expectations regarding the structure of regional networks have to be moderate.

${ }^{5}$ The number of employees is dependent upon which definition of the chemical industry is used (Schwartau 1980).

${ }^{6}$ The chemical industry union - today's IG BCE (Industriegewerkschaft Bergbau Chemie Energie) - was generally supportive of this policy without having a major impact of its own. This appears typical for the 
traditionally co-operative relationship between employers and unions in the German chemical industry (Schumann et al. 1994).

${ }^{7}$ Interestingly, Peter Breitenstein, the director of the chemical park in 1999 was directly involved in splitting off tasks, such as energy supply, factory security, logistics and telecommunication services, in his prior position at the Treuhandanstalt/Bundesanstalt für vereinigungsbedingte Sonderaufgaben (BvS).

${ }^{8}$ Similarly, Guardian Flachglas also established production outside the former Kombinat in Wolfen.

${ }^{9}$ Two other management buy-outs in Bitterfeld-Wolfen were CBW Chemie GmbH Bitterfeld-Wolfen, which was established by the former Treuhandanstalt manager Max Bräutigam, and TDA Technische Dienste und Anlagen $\mathrm{GmbH}$.

${ }^{10}$ Some would argue that this will be a feature of most regional economies in the future, as globalisation would weaken regional clusters (e.g. Land 2006). However, case studies over the past decade have shown that regional industry clusters continue to be major arenas of economic production and do not necessarily dissolve due to globalisation (Bathelt et al. 2004).

${ }^{11}$ It should be mentioned, however, that some chemical regions in West Germany also developed toward hollow complexes, particularly related to major global restructuring processes as in the case of some of the former chemical core regions of Hoechst and Rhône-Poulenc in Germany and France after the Aventis merger (Bathelt and Kappes 2008). 